\title{
Structural changes of mucous membrane and the presence of immunoglobulins in small intestines of neonatal pigs
}

\author{
Tomáš Kanka ${ }^{1}$, Michal Rolinec ${ }^{2}$, Danka Št’astná ${ }^{1}$ Ivan Imrich ${ }^{1}$, Daniel Bíro² \\ Branislav Gálik ${ }^{2}$
}

Slovak University of Agriculture in Nitra, Faculty of Agrobiology and Food Resources, ${ }^{1}$ Department of Animal Nutrition, ${ }^{2}$ Department of Veterinary Discipline, Nitra, Slovak Republic

\author{
Received October 17, 2012 \\ Accepted June 19, 2013
}

\begin{abstract}
The structure of the small intestine of neonatal pigs has an important effect on immunoglobulin absorption. The aim of the experiment was to observe changes in the mucous membrane and the presence of immunoglobulins in the intestines of piglets during the first hours of their postnatal lives. In total, 80 piglets of the Large White breed were divided into two groups of 40 pigs. One group (control) came from an infection-free breeding, the other (experimental) group came from a breeding with the reproduction and respiration syndrome of pigs. Samples $(n=80)$ of duodenum, jejunum and ileum were taken at intervals of $0,3,6$ and $12 \mathrm{~h}$ after colostrum intake in order to carry out histological tests. Primary pig antibodies were detected by immunohistochemical staining. The low content of immunoglobulins IgG, IgA and IgM was detected in all segments of intestines of precolostral piglets. Difference $(P<0.05)$ in size of the mucous membrane was found in the duodenum at the interval of 0,3 and $6 \mathrm{~h}(46.03 \%)$, in the jejunum at 0 and $12 \mathrm{~h}$ $(45.98 \%)$ and in favour of the control group. Compared to the control group, more $\operatorname{Ig}(P<0.01)$ antibodies were observed in the experimental group: in the duodenum IgG at $12 \mathrm{~h}(37.22 \mathrm{vs}$. $10.81 \%), \operatorname{IgA}, 6 \mathrm{~h}(43.29$ vs. $16.71 \%), \operatorname{IgM}, 12 \mathrm{~h}(25.29$ vs. $8.40 \%)$, in the jejunum at $\operatorname{IgG} 12 \mathrm{~h}$ (23.97 vs. $9.96 \%)$, IgA, 0 h (0.48 vs. $0.37 \%)$ and IgM, 3 h (21.80 vs. $10.10 \%)$, in the ileum IgG, $0 \mathrm{~h}(0.38$ vs. $0.29 \%)$, IgA, 3 h (20.46 vs. $6.45 \%)$, IgM, 3 h (31.5 vs. $12.29 \%)$. We can conclude that the colostrum intake and the presence of reproduction and respiration syndrome of pigs resulted in changes of microscopic structures of intestines as well as in the presence of Ig in piglet intestines. These mucosal changes significantly affect the development of passive immunity in piglets in the postnatal period.
\end{abstract}

Immunity, immunohistochemistry, histology, gut, piglets

Immunoglobulins taken from colostrum during the first hours after birth play an important role in the postnatal development of the immune system. Immunoglobulins are glycoproteins which consist of $82-96 \%$ proteins and $4-18 \%$ carbohydrates (Biss et al. 2002). Immunoglobulins have two main functions. First, they recognize and take up an antigen and then they activate the body's defence mechanism. According to Roitt et al. (2001), immunoglobulins are responsible for contact between the substances strange to the body and phagocyting cells. Antibodies are also able to affect viruses and bacterial toxins by the process of neutralization (Roitt et al. 2001). The acquisition of humoral immunity through the transfer of IgG from mother to offspring shows species-specific differences (Cervenak and Kacskovics 2009). Klobasa et al. (1991) claimed that pigs have the following categories of immunoglobulins: IgG, $\operatorname{IgA}$ and $\operatorname{IgM}$ as well as their sub-categories. A piglet is able to take mainly IgG via colostrum during its first 24-36 h after birth to secure its humoral immunity. Local protection of intestinal mucosa with the help of IgA is ensured via milk intake (Wagstrom et al. 2000). Passive immunity is secured by colostrum and milk intake till sufficient production of antibodies starts (3-5 weeks). The gut closure is a limiting factor for immunoglobulin intake; $t$ is defined as the final transport of immunoglobulins via basolateral membrane of entocytes into the blood stream of piglets (Rooke and Bland 2002). Absorption capacity of enterocytes is not

Address for correspondence:

Ing. Tomáš Kanka, PhD.

Department of Veterinary Discipline

Faculty of Agrobiology and Food Resources

Slovak University of Agriculture

Tr. A. Hlinku 2, 94976 Nitra, Slovakia

Phone: +421376414504

E-mail: Tomas.Kanka@uniag.sk

http://actavet.vfu.cz/ 
influenced only by the time from birth but also by the time of colostrum intake or intake of other substances. Enterocytes of the small intestine receive immunoglobulins of colostrum by non-specific macrocytosis and they store them in vacuoles. The enterocytes created in embryo before birth have this ability of pinocytosis. Enterocytes created after birth do not have the ability of pinocytosis of unharmed proteins. Enterocytes receive immunoglobulins and other macromolecules also after gut closure but these are not transferred into the neonatal blood stream (Klobasa et al. 1991). The resistance of pigs to viruses, bacteria and parasites is influenced by concentration of immunoglobulins and therefore, the colostrum of sows is a source of the first protection of piglets against pathogens (Kovářù et al. 2002). Performance of pigs is directly affected by the pigs' health status (Bučko et al. 2012).

The aim of our research was to study the structure of duodenum, jejunum and ileum of piglets during the first $12 \mathrm{~h}$ after birth and to determine the presence of $\operatorname{Ig}(\operatorname{IgG}, \operatorname{IgM}, \operatorname{IgA})$ in their small intestines before and after the colostrum intake.

\section{Materials and Methods}

In the experiment 20 sows of the breed Large White $\times$ Landrace were used. The sows were divided into two groups, one (experimental, $\mathrm{n}=10$ ) group with reproduction and respiration syndrome of pigs (RRSP) and the other one (control, $\mathrm{n}=10$ ) without infection. The average body weight of sows was $185 \pm 25 \mathrm{~kg}$. Four piglets were taken from each sow (totally 80 piglets). The piglets were selected immediately after birth and before the colostrum intake at intervals of $0 \mathrm{~h}$ (20 piglets), $3 \mathrm{~h}$ (20 piglets), $6 \mathrm{~h}$ (20 piglets) and $12 \mathrm{~h}(20$ piglets $)$ after the colostrum intake. The piglets of both groups received colostrum up to half an hour after birth.

The autopsy of piglets was carried out with dietylether $(25 \mathrm{ml})$ after their euthanasia. The samples $($ size $5 \times$ $5 \mathrm{~mm}$ ) for histological and immunohistochemical testing were taken from the duodenum, jejunum and ileum. The intestine of each piglet was washed by saline before the sample was taken. For the purpose of histological studies, the samples were fixed in 10\% formol. After washing, the samples were submerged in paraffin. The rotary microtome (MicroTec, Laborgeräte $\mathrm{GmbH}$, Walldorf, Germany) was used to prepare histological slices (7-8 $\mu \mathrm{m})$ that were stained by haematoxylin-eosin. Deparaffinized a dehydrated slices were used for immunohistochemical reactions with primary pig antibodies produced on rabbits (Bethyl Laboratories, Montgomery, USA). The results were qualitatively and quantitatively evaluated.

Statistical and graphical evaluations were performed by using light microscope (Olympus Provis AX) and by program used for evaluation of individual morphological structures-Statgraphics ver.7, Image ProPlus (Spectra Services Inc, NY). Significance $(P<0.05)$ was evaluated by Duncan test using the program SAS system 9.1. (SAS Institute Inc.). The experiment 1/0662/11-1 was approved by the ethics committee and realized as a part of project n. 1/0662/11.

\section{Results}

While analyzing our results, we focused on the changes occurring in the intestinal mucous membrane (Table 2). In all segments of the small intestine, gradual increase of the size of the mucous membrane and epithelium was found. The highest values were reached at the interval between hour 6 and 12 after the colostrum intake. The lowest activity was detected in the ileum $3 \mathrm{~h}$ after the colostrum intake (Tables 2, 3). In the relative size of epithelium, the activity in ileum increased (comparable with jejunum) $12 \mathrm{~h}$ after colostrum intake (Table 3). The presence of evaluated components of the duodenum, jejunum and ileum wall was expressed by relative values. Table 1 shows the presence of immunoglobulins (\%) in the small intestine at evaluated time intervals $0 \mathrm{~h}$, and subsequently 3,6 and $12 \mathrm{~h}$ after colostrum intake. Notable differences connected with the presence of immunoglobulin classes between the control experimental groups were observed in individual segments of small intestine in favour of the control group. Immunoglobulins in individual segments of small intestine were present at all time intervals except for the duodenum of the control group (IgM at $6 \mathrm{~h}$ ) and the jejunum (IgA at $6 \mathrm{~h}$ ) with the increasing tendency mainly from hour 3 to 6 after the colostrum intake (Table 1). After that, the gradual decrease was observed. After colostrum intake in the duodenum (Table 1), the content of immunoglobulins in the control group increased. In the jejunum, significant differences were observed only in the control 
Table 1. The Ig positive areas of mucous membrane in small intestine of neonatal pigs (\%)

\begin{tabular}{|c|c|c|c|c|c|}
\hline & Sampling time & Group & Duodenum & Jejunum & Ileum \\
\hline \multirow{8}{*}{$\mathrm{IgG}$} & $0 \mathrm{~h}$ & $\mathrm{C}$ & $0.7 \pm 0.12^{\mathrm{a}}$ & $0.82 \pm 0.06^{\mathrm{b}}$ & $0.38 \pm 0.04^{\mathrm{b}}$ \\
\hline & & $\mathrm{E}$ & $0.56 \pm 0.15$ & $0.53 \pm 0.05$ & $0.29 \pm 0.03$ \\
\hline & $3 \mathrm{~h}$ & $\mathrm{C}$ & $19.96 \pm 21.51$ & $22.68 \pm 2.54^{\mathrm{b}}$ & $15.38 \pm 4.63$ \\
\hline & & $\mathrm{E}$ & $5.32 \pm 4.71$ & $11.63 \pm 1.79$ & $13.55 \pm 2.07$ \\
\hline & $6 \mathrm{~h}$ & $\mathrm{C}$ & $28.75 \pm 9.68^{\mathrm{a}}$ & $25.32 \pm 8.51^{\mathrm{a}}$ & $11.85 \pm 2.15$ \\
\hline & & $\mathrm{E}$ & $16.05 \pm 4.16$ & $12.71 \pm 2.13$ & $9.17 \pm 1.92$ \\
\hline & $12 \mathrm{~h}$ & $\mathrm{C}$ & $37.22 \pm 6.75^{\mathrm{b}}$ & $23.97 \pm 6.52^{\mathrm{b}}$ & $8.61 \pm 1.73$ \\
\hline & & $\mathrm{E}$ & $10.81 \pm 3.83$ & $9.96 \pm 1.97$ & $6.76 \pm 1.94$ \\
\hline \multirow{8}{*}{$\operatorname{Ig} \mathrm{A}$} & $0 \mathrm{~h}$ & $\mathrm{C}$ & $0.85 \pm 0.14^{b}$ & $0.48 \pm 0.09^{\mathrm{b}}$ & $0.28 \pm 0.02^{b}$ \\
\hline & & $\mathrm{E}$ & $0.59 \pm 0.05$ & $0.37 \pm 0.04$ & $0.16 \pm 0.05$ \\
\hline & $3 \mathrm{~h}$ & $\mathrm{C}$ & $34.68 \pm 9.09^{b}$ & $13.18 \pm 5.69$ & $20.46 \pm 2.84^{b}$ \\
\hline & & $\mathrm{E}$ & $14.27 \pm 3.41$ & $8.32 \pm 2.25$ & $6.45 \pm 2.62$ \\
\hline & $6 \mathrm{~h}$ & $\mathrm{C}$ & $43.29 \pm 6.47^{b}$ & $11.05 \pm 2.63$ & $13.89 \pm 2.04$ \\
\hline & & $\mathrm{E}$ & $16.71 \pm 2.14$ & $8.49 \pm 1.97$ & $13.38 \pm 0.89$ \\
\hline & $12 \mathrm{~h}$ & $\mathrm{C}$ & $26.84 \pm 17.75^{\mathrm{a}}$ & $11.60 \pm 10.26$ & $9.06 \pm 1.75$ \\
\hline & & $\mathrm{E}$ & $13.29 \pm 2.62$ & $9.99 \pm 1.85$ & $9.59 \pm 2.08$ \\
\hline \multirow{8}{*}{$\operatorname{IgM}$} & $0 \mathrm{~h}$ & $\mathrm{C}$ & $0.43 \pm 0.05^{\mathrm{b}}$ & $0.48 \pm 0.05^{\mathrm{b}}$ & $0.18 \pm 0.02$ \\
\hline & & $\mathrm{E}$ & $0.30 \pm 0.05$ & $0.27 \pm 0.05$ & $0.16 \pm 0.03$ \\
\hline & $3 \mathrm{~h}$ & $\mathrm{C}$ & $30.98 \pm 20.68^{a}$ & $21.80 \pm 3.46^{\mathrm{b}}$ & $31.5 \pm 10.89^{b}$ \\
\hline & & $\mathrm{E}$ & $4.14 \pm 1.27$ & $10.10 \pm 1.99$ & $12.29 \pm 2.31$ \\
\hline & $6 \mathrm{hs}$ & $\mathrm{C}$ & $18.53 \pm 7.18^{\mathrm{a}}$ & $21.22 \pm 2.50^{b}$ & $12.18 \pm 1.45$ \\
\hline & & $\mathrm{E}$ & $9.97 \pm 1.36$ & $9.24 \pm 3.33$ & $10.36 \pm 1.59$ \\
\hline & $12 \mathrm{~h}$ & $\mathrm{C}$ & $25.29 \pm 8.47$ & $5.53 \pm 2.90$ & $9.10 \pm 1.14$ \\
\hline & & $\mathrm{E}$ & $8.40 \pm 1.91$ & $4.2 \pm 1.17$ & $7.25 \pm 2.16$ \\
\hline
\end{tabular}

$\mathrm{C}$ - control group, $\mathrm{E}$ - experimental group. Data are expressed as $\overline{\mathrm{x}} \pm \mathrm{SD},{ }^{\mathrm{ab}}$ - significant difference between the control and experimental group at the level of importance a $P<0.05,{ }^{\text {b }} P<0.01$.

Table 2. Size of mucous membrane in small intestine of neonatal pigs (\%)

\begin{tabular}{|c|c|c|c|c|c|c|c|c|}
\hline \multirow[b]{3}{*}{ Group } & \multicolumn{8}{|c|}{ Sampling time } \\
\hline & $0 \mathrm{~h}$ & & $3 \mathrm{~h}$ & & $6 \mathrm{~h}$ & & $12 \mathrm{~h}$ & \\
\hline & $\mathrm{C}$ & $E$ & $\mathrm{C}$ & $\mathrm{E}$ & $\mathrm{C}$ & $\mathrm{E}$ & $\mathrm{C}$ & $\mathrm{E}$ \\
\hline \multicolumn{9}{|c|}{ Duodenum } \\
\hline & $29.86 \pm 8.06^{\mathrm{a}}$ & $18.41 \pm 6.63$ & $43.76 \pm 11.29^{a}$ & $\begin{array}{r}31.91 \pm 7.85 \\
\text { Jejunum }\end{array}$ & $46.03 \pm 9.09^{\mathrm{a}}$ & $39.13 \pm 6.11$ & $46.26 \pm 7.91$ & $38.45 \pm 9.51$ \\
\hline & $41.40 \pm 28.24^{\mathrm{a}}$ & $21.75 \pm 10.33$ & $36.67 \pm 16.10$ & $\begin{array}{c}27.47 \pm 10.37 \\
\text { Ileum }\end{array}$ & $37.38 \pm 11.16$ & $37.55 \pm 9.57$ & $45.98 \pm 11.43^{\mathrm{a}}$ & $31.11 \pm 10.20$ \\
\hline & $20.64 \pm 7.36 a$ & $15.78 \pm 5.23$ & $24.93 \pm 8.02$ & $21.42 \pm 5.90$ & $37.38 \pm 11.16$ & $21.52 \pm 8.37$ & $27.68 \pm 7.07^{\mathrm{a}}$ & $21.81 \pm 6.00$ \\
\hline
\end{tabular}

$\mathrm{C}$ - control group, $\mathrm{E}$ - experimental group. Data are expressed as $\overline{\mathrm{x}} \pm \mathrm{SD},{ }^{\mathrm{a}}$ - significant difference between the control and experimental group at the level of importance $(P<0.05)$.

group (Table 1). As for IgG, its content increased $3 \mathrm{~h}$ after colostrum intake (Plate IX, Fig 1, Plate X, Fig 2) and IgM increased in comparison with $0 \mathrm{~h}$ before colostrum intake. In the ileum of animals of the control group (Table 1), higher values of immunoglobulins were determined only in IgM class. As for class IgA, values of immunoglobulins increased $3 \mathrm{~h}$ 
Table 3. Size of epithelium in small intestine of neonatal pigs (\%)

\begin{tabular}{|c|c|c|c|c|c|c|c|c|}
\hline \multirow[b]{3}{*}{ Group } & \multicolumn{8}{|c|}{ Sampling time } \\
\hline & $0 \mathrm{~h}$ & & $3 \mathrm{~h}$ & & $6 \mathrm{~h}$ & & $12 \mathrm{~h}$ & \\
\hline & $\mathrm{C}$ & $\mathrm{E}$ & $\mathrm{C}$ & E & $\mathrm{C}$ & $\mathrm{E}$ & $\mathrm{C}$ & $E$ \\
\hline \multicolumn{9}{|c|}{ Duodenum } \\
\hline & $78.79 \pm 2.14$ & $79.38 \pm 2.68$ & $83.46 \pm 2.63$ & $\begin{array}{r}84.58 \pm 2.79 \\
\text { Jejunum }\end{array}$ & $81.79 \pm 3.21$ & $82.72 \pm 2.34$ & $77.64 \pm 3.18$ & $79.80 \pm 2.96$ \\
\hline & $77.14 \pm 5.05$ & $76.93 \pm 5.29$ & $81.76 \pm 3.36$ & $\begin{array}{c}82.66 \pm 2.28 \\
\text { Ileum }\end{array}$ & $81.97 \pm 2.01$ & $82.77 \pm 2.10$ & $82.47 \pm 2.90$ & $82.53 \pm 3.18$ \\
\hline & $80.62 \pm 8.01$ & $80.92 \pm 7.88$ & $84.16 \pm 3.50$ & $84.96 \pm 2.53$ & $84.99 \pm 2.04$ & $85.37 \pm 1.56$ & $82.65 \pm 2.73$ & $82.65 \pm 2.08$ \\
\hline
\end{tabular}

$\mathrm{C}$ - control group, E - experimental group. Data are expressed as $\overline{\mathrm{x}} \pm \mathrm{SD}$

after colostrum intake. Other values of immunoglobulins were incomparably lower in the control group as well as in the experimental group. In the control group, IgG prevailed among all immunoglobulins.

\section{Discussion}

The active components present in the wall of the small intestine of neonatal piglets, i.e. the mucous membrane and epithelium, are most important because of their ability to absorb immunoglobulins, and for this reason they were evaluated. According to the type of placenta, pigs belong to those species of farm animals that receive almost no immunoglobulins during their prenatal period (Toman 2000). We detected some classes of immunoglobulins in the small intestine even in the precolostral period. It indicates that some classes of immunoglobulins can be present even in the prenatal period of pigs. In spite of the fact that the concentration of immunoglobulins in the prenatal period is incomparably lower than after colostrum intake, it is probable that they will work as effective immune factors. It is important to emphasize that in both studied groups, the concentrations were greatly variabile. This can be linked to the prenatal conditions of pigs' development. For the intake of immunoglobulins, intestinal permeability is very important. During the first hours after birth, intestinal permeability is total. Ig resorption is lowered by half during $20 \mathrm{~h}$ after birth and it is completely stopped after $36 \mathrm{~h}$ (Tizard 1996). The structure of the piglets' intestines has to correspond to this given time because the time of the socalled closure of epithelium is very important for the intake of macromolecular substances (Pastoret and Bazin 1998). Epithelial cells by maturation lose their absorption ability and the so-called gut closure occurs. It is assumed that the highest intake of immunoglobulins is connected with piglets up to $10-12 \mathrm{~h}$ of their postnatal lives which in turn also influences the amount of immunoglobulins in the received colostrum and the ability to absorb immunoglobulins from the intestine into blood (Tuchserer and Gershwin et al. 2002). Murata and Namioka (2004) discovered that the completion of absorption of colostral immunoglobulins in the small intestine occurs $72 \mathrm{~h}$ after colostrum intake, whereas the completion of absorption in the duodenum occurs $2 \mathrm{~h}$ after colostrum intake, in the jejunum $24 \mathrm{~h}$ after colostrum intake and in the ileum $48 \mathrm{~h}$ after colostrum intake. According to Murata and Namioka (2004), the completion of the intake of colostral immunoglobulins occurs from the proximal to the distal segment of the small intestine on the third day after birth. Széky et al. (1999) claim that the highest absorption of immunoglobulins from colostrum takes place in the epithelial cells of the mucous membrane of the jejunum and it reaches almost two thirds of the ileum. According to Tuboly and Nagy (2000), the 
most intensive absorption of immunoglobulins occurs in the ileum from the hour 4 after colostrum intake and it reaches its peak between the hours 8 and 12 after colostrum intake. We assume that the gut closure is in progress up to $12 \mathrm{~h}$ after birth, because the highest values of Ig were detected between hours 3 and 6 after colostrum intake with a subsequent decrease. Higher values of immunoglobulins in the controlled group are probably connected with the resistance against RRSP which was confirmed in the experimental group. The presence of all immunoglobulins was significantly lower with this group of animals. IgG belongs to the dominant Ig classes in the body as well as to the most important antibodies of the secondary immune response (Roitt et al. 2001). Rolinec et al. (2012) also claimed lower concentrations of all the mentioned classes of immunoglobulins in the colostrum of sows infected by PRRS.

It is very difficult to compare the data about morphometric changes of the intestinal mucous membrane observed in our experiment because we have not found literature dealing with the quantification of the observed structures of the small intestine. Only the size, circumference and surface of villi are evaluated in the available literature. Part of the changes in the intestinal mucosa is the intensively develop of the intestinal villi during the first 3 weeks (Skrzypek et al. 2005). From the evaluated relative size of the mucous membrane and epithelium it is evident that the duodenum and jejunum (Table 2, 3) are the most active segments of the small intestine $3 \mathrm{~h}$ after colostrum intake which is in agreement with report of Yang and Parkhouse (1998). Murata and Namioka (2004) reported that jejunum is most active up to $3 \mathrm{~h}$ after colostrum intake. At that time, the activity of duodenum was lower. This can be marked as the gut closure of the small intestine which is described by Sheven and Febiger (2001). The lowest values of the size of the mucous membrane in the ileum and duodenum were observed in the samples taken before colostrum intake (Table 2). The highest activity was connected with the jejunum (Table 2). Similar data about neonatal pigs are mentioned by Roffler et al. (2003). In the intestine mucosa of neonatal piglets from positive PRRS sows infection, we found lower percentage of immunoglobulins.

\section{Acknowledgements}

This study was supported by Grant Agency of the Slovak Ministry of Education, Science, Research and Sport and Slovak Academy of Sciences (projects n. 1/0662/11).

\section{References}

Biss B, Rovenský J, Buc M 2002: Clinical pharmacology of immunopharmacum memorix of clinical pharmacology, SAP Bratislava, 879 p.

Bučko O, Lehotayová A, Petrák J, Vavrišínová K, Šimko M, Juráček M 2012: Effect of organic chromium to carcass composition and chemical composition of adductor muscle in large white breed. Res Pig Breed. 6: 5-9

Cervenak J, Kacskovics I 2009: The neonatal Fc receptor plays a crucial role in the metabolism of IgG in livestock animals. Vet Immunol Immunopathol 128: 171-177

Klobasa F, Habe E, Werhahn E 1991: Study on the absorption of colostral immunoglobulins in newborn piglets: Effect of water or glucose solution on the permeability of newborn intestine. Berl Münch Tierärztl Wschr 104: 37-41

Kovářů F, Kovářů H, Fišerová A, Matalová E, Zelníčková P, Landa L, Palíková M 2002: Physiological and immunological profiles after intrauterine immunization. Acta Vet Brno 71: 487-493

Murata VA, Namioka S 2004: Effect of early weaning on the development of immune cells in the pig small intestine. Vet Immunol Immunopathol 54: 329-337

Pastoret S, Bazin H 1998: Proceedings of the fourth internacional veterinary imunology symposium. Vet Immunol Immunopathol 54: 253-257

Roffler KU 2003: Postnatal adaptation of the gastrointestinal tract in neonatal pigs. Livestock Prod Sci 62: 84-92

Roitt IM, Brostoff J, Male DK 2001: Short Textbook of Immunology Auflag Thieme Verlag Stuttgart 2: 211-216

Rolinec M, Bíro D, Št’astný P, Gálik B, Šimko M, Juráček M 2012: Immunoglobulins in colostrum of sows with porcine reproductive and respiratory syndrome - PRRS. J Central European Agricul 13: 303-311

Rooke JA, Bland IM 2002: The aquisition of the passive imunity in the new-born piglet. Livestock Prod Sci 78 : $13-23$ 
Sheven PE, Febiger H 2001: Imunity in the fetus and newborn. In Tizard IR 2008: Veterinary immunology. $8^{\text {th }}$ ed, An Introduction WB Saunders Company Philadelphia USA, pp. 495-502

Skrzypek T, ValverdePiedra JL, Skrzypek H, Woliński J, Kazimierczak W, Szymańczyk S, Pawłowska M, Zabielski R 2005: Light and scanning electronmicroscopy evaluation of the postnatal small intestina mucosa development in pigs. J Physiol Pharmacol 56 Suppl 3: 71-87

Széky H, Rátz A 1999: Absorption of colostral immunoglobulins in suckling piglets. Microbiol Akad Sci Hung 86: $99-100$

Tizard IR 1996: Essential immunology. 6 ed, Blackwel, London, 438 p.

Toman M, Bárta O, Dostál J, Faldyna M, Holáň V, Hořín P, Hruban V, Knotek Z, Kopecký J, Koudela B, Krejčí J, Plachý J, Pospíšil R, Pospíšil Z, Rybnikář A, Ryšánek D, Smola J, Šíma P, Tlaskalová H, Trebichavský I, Veselský L 2000: Veterinary Immunology, Grada Praha, 413 p. ISBN 80-7169-727-3

Tuboly S, Nagy I 2000: Intestinal absorption of colostral lymphoid cells in newborn piglets. Vet Immunol Immunopathol 20: 75-85

Tuchserer JK, Gershwin LJ 2002: Proceedings of the fourth international veterinary immunology symposium. Vet Immunol Immunopatol 65: 18-23

Wagstrom EA, Yoon KJ, Zimmermann JJ 2000: Immune components in porcine mammary secretions. Viral Immunol 13: 383-397

Yang H, Parkhouse RME 1998: Prenatal ontogeny of lymphocyte subpopulations in pigs. Immunol 93: 487-492 
Plate IX

Kanka T. et al.: Structural changes... pp. 317-322

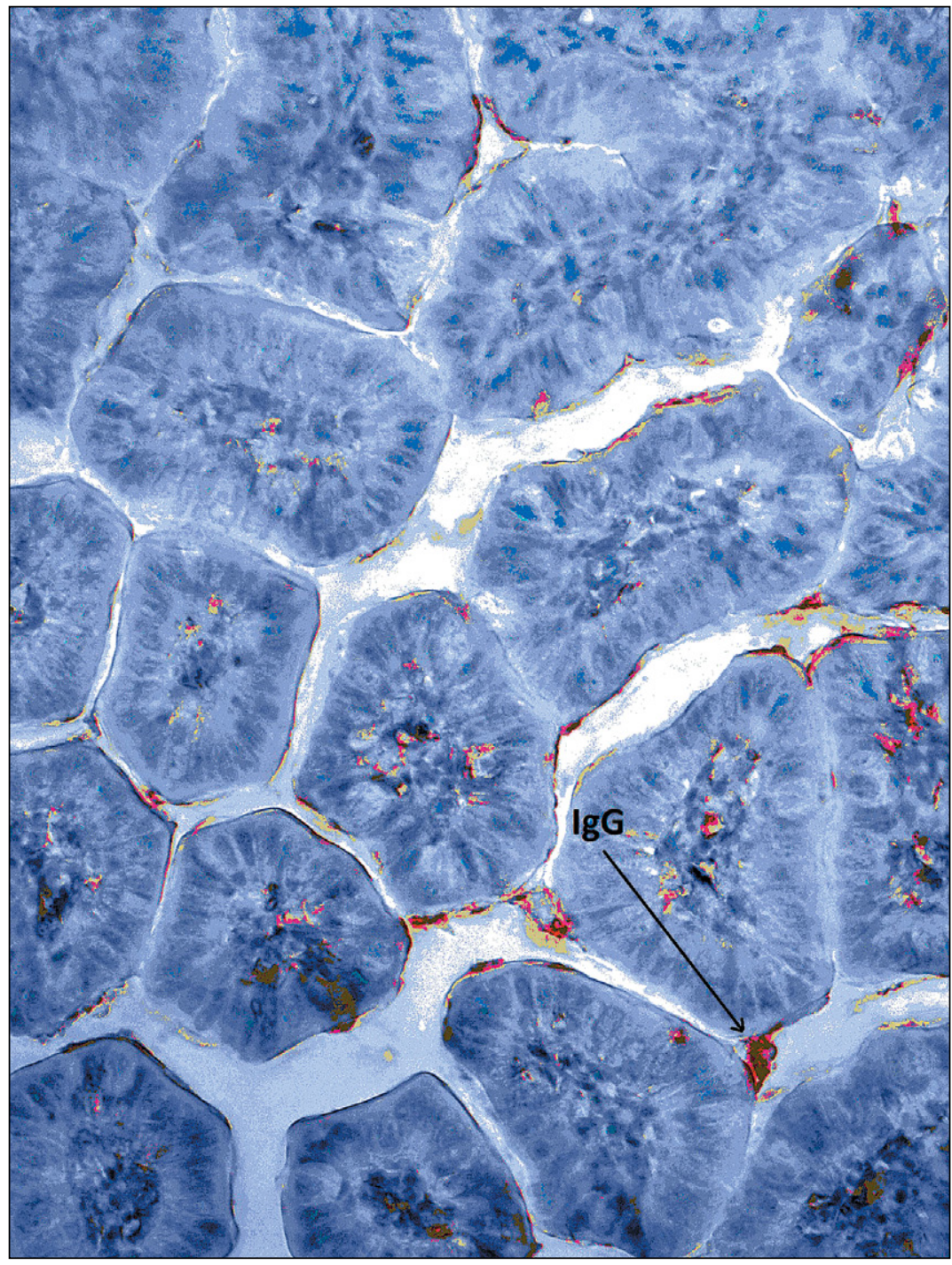

Fig. 1. Immunoglobulin $\mathrm{IgG}$ in jejunum at $0 \mathrm{~h}(\times 200$, immunohistochemical staining, Bethyl Laboratories, Montgomery, USA) 
Plate X

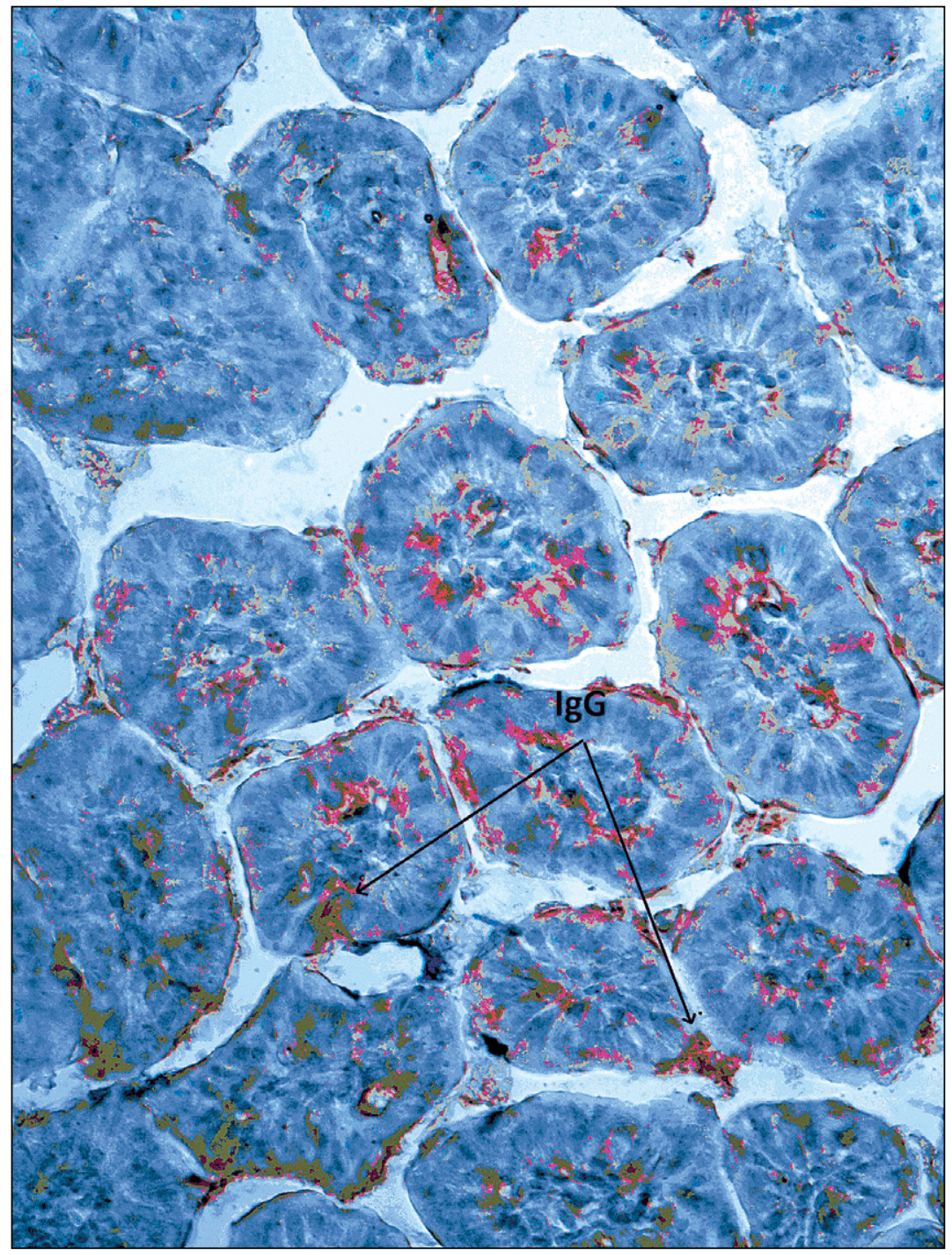

Fig. 2. Immunoglobulin $\mathrm{IgG}$ in jejunum at $6 \mathrm{~h}(\times 200$, immunohistochemical staining, Bethyl Laboratories, Montgomery, USA) 